\title{
Immunoglobulin G Is a Platelet Alpha Granule-secreted Protein
}

\author{
James N. George, Sherry Saucerman, Shirley P. Levine, and Linda K. Knieriem \\ San Antonio, Texas 78284 \\ Dorothy F. Bainton \\ Department of Pathology, University of California School of Medicine, San Francisco, California 94143
}

Division of Hematology, Department of Medicine, University of Texas Health Science Center, and Audie L. Murphy Veterans Hospital,

\begin{abstract}
It has been known for 27 yr that blood platelets contain IgG, yet its subcellular location and significance have never been clearly determined. In these studies, the location of IgG within human platelets was investigated by immunocytochemical techniques and by the response of platelet IgG to agents that cause platelet secretion. Using frozen thin-sections of platelets and an immunogold probe, IgG was located within the $\alpha$-granules. Thrombin stimulation caused parallel secretion of platelet IgG and two known $\alpha$-granule proteins, platelet factor 4 and $\beta$ thromboglobulin, beginning at $0.02 \mathrm{U} / \mathrm{ml}$ and reaching $100 \%$ at $0.5 \mathrm{U} / \mathrm{ml}$. Thrombin-induced secretion of all three proteins was inhibited by prostaglandin $E_{1}$ and dibutyryl-cyclic AMP. Calcium ionophore A23187 also caused parallel secretion of all three proteins, whereas ADP caused virtually no secretion of any of the three. From these data and a review of the literature, we hypothesize that plasma IgG is taken up by megakaryocytes and delivered to the $\alpha$-granules, where it is stored for later secretion by mature platelets.
\end{abstract}

\section{Introduction}

IgG was first identified in blood platelets by Salmon (1) in 1958. Davey and Lüscher $(2,3)$ confirmed this observation in 1966 and demonstrated that IgG was secreted from platelets in response to thrombin. Later, it was suggested that IgG was a surface component of platelets because it was removed from platelets by trypsin treatment (4); however, this removal may have been a result of trypsin-induced platelet secretion (5). The clinical relevance of quantitative assays for platelet-associated IgG was promoted by the demonstration of increased concentrations of platelet IgG in patients with immune thrombocytopenic purpura (6-8). These studies assumed that IgG was an antiplatelet antibody and that the assays were analogous to the Coombs' antiglobulin test used with erythrocytes in autoimmune hemolytic disease. Since that time, numerous techniques for measuring platelet IgG have been developed to identify patients with disorders of immunologic platelet destruction (reviewed by McMillan [9] and by Kelton [10]).

Address correspondence and reprint requests to Dr. George. Received for publication 11 June 1985.

J. Clin. Invest.

(c) The American Society for Clinical Investigation, Inc.

0021-9738/85/11/2020/06 \$1.00

Volume 76, November 1985, 2020-2025
The significance and subcellular location of platelet IgG remain unclear (11). Various assays have shown the IgG concentration of normal platelets to be $1-10 \mathrm{fg} /$ platelet $(4,000-40,000$ molecules/platelet) $(9,12)$. Comparisons of assays on intact and lysed platelets have suggested that one-third to two-thirds of platelet IgG is on the cell surface $(13,14)$. However some assays have demonstrated markedly less surface IgG, 146-235 molecules/platelet (15-17). If platelet IgG is contained within secretory granules, then the techniques of platelet washing and incubation, which can easily cause platelet secretion (18), may be critical and uncontrolled variables affecting these data.

The objective of our experiments was to further characterize the IgG associated with normal platelets. We have demonstrated that IgG is located within the platelet $\alpha$-granules and that its secretion from platelets is parallel to that of two known $\alpha$-granule proteins (19-21): platelet factor 4 (PF4) ${ }^{1}$ and $\beta$-thromboglobulin (BTG).

\section{Mothods}

Immunocytochemical procedures. Platelets were fixed in 8\% paraformaldehyde in $0.1 \mathrm{M}$ Pipes buffer, $\mathrm{pH} 7.2$, by dripping blood directly from the needle into the fixative maintained at $37^{\circ} \mathrm{C}$, as described by Stenberg et al. $(20,21)$. Platelets were washed in the same buffer containing $10 \%$ (wt/vol) sucrose. They were infiltrated for $30 \mathrm{~min}$ with $2.1 \mathrm{M}$ sucrose, embedded in the sucrose solution, frozen, and stored in liquid nitrogen. Sections were cut on an ultracut E (A. O. Reichert, Los Angeles, CA). The frozen thin-section techniques described by Tokuyasu (22) were used, with the modifications for the use of colloidal gold described by Griffiths et al. (23). The primary antibody, which was prepared against human IgG (heavy and light chains) in the rabbit, was obtained from Miles Scientific, Inc., Naperville, IL. It was used at dilutions of 1:10-1: 1,000. The immunogold probe, which was used in a dilution of 1:50, was goat anti-rabbit IgG linked to 5-nm colloidal gold particles (GAR5) (Jansson Pharmaceuticals, Beerse, Belgium). The immunological techniques were performed as previously described $(20,21)$.

Platelet preparation for secretion studies. Blood was drawn from normal volunteers who had not ingested aspirin or other agents that inhibit platelet function for the previous $10 \mathrm{~d}$. The blood was anticoagulated with 0.1 volume of $3.8 \%$ sodium citrate and $0.5 \mu \mathrm{g} / \mathrm{ml}$ prostaglandin (PGE) (Sigma Chemical Co., St. Louis, MO). Platelet-rich plasma was obtained by centrifugation, and the platelets were washed twice in Tyrode's buffer $(138 \mathrm{mM} \mathrm{NaCl}, 29 \mathrm{mM} \mathrm{KCl}, 12 \mathrm{mM} \mathrm{NaHCO}, 0.4 \mathrm{mM}$ $\mathrm{NaHPO}_{4}, 1 \%$ glucose, $0.35 \%$ bovine serum albumin [BSA]) (24), $\mathrm{pH}$ 6.5 , containing $50 \mathrm{ng} / \mathrm{ml} \mathrm{PGE}_{1}$ (referred to as "wash buffer"). Platelets

1. Abbreviations used in this paper: BTG, $\beta$-thromboglobulin; db-cAMP, $\mathrm{N}^{6} \mathrm{O}^{2}$-dibutyryl adenosine 3',5'monophosphate cyclic AMP; ELISA, enzyme-linked immunosorbant assay; PF4, platelet factor 4; PG, prostaglandin. 
were resuspended in Tyrode's buffer with added $\mathrm{CaCl}_{2}(2 \mathrm{mM})$ and $\mathrm{MgCl}_{2}$ (1 mM) and without $\mathrm{PGE}_{1}$ at $\mathrm{pH} 7.4$ (referred to as "resuspension buffer").

Platelet secretion. Human $\alpha$-thrombin, $2,600 \mathrm{U} / \mathrm{mg}$, was a gift from Dr. John W. Fenton II, Albany, NY. Calcium ionophore A23187 and ADP were obtained from Sigma Chemical Co. Purified human fibrinogen was a gift from Dr. Rodger McEver, San Antonio, TX. The following reaction mixtures were used: thrombin, $0.01-0.5 \mathrm{U} / \mathrm{ml}$; ionophore A23187, 0.1-5.0 $\mu \mathrm{M}$, with leupeptin (0.4 mM), an inhibitor of the endogenous platelet calcium-dependent protease (25); and ADP, 2-50 $\mu \mathrm{M}$, with fibrinogen $(0.5 \mathrm{mg} / \mathrm{ml})$. To inhibit thrombin-induced platelet secretion in some experiments, $\mathrm{PGE}_{1}$ and $\mathrm{N}^{6} \mathrm{O}^{2}$-dibutyryl adenosine 3',5'monophosphate cyclic AMP (db-cAMP) (Sigma Chemical Co.) were added to the platelet suspension in final concentrations of $10 \mu \mathrm{g} / \mathrm{ml}$ and $1 \mathrm{mM}$, respectively (26). The final suspensions, $1 \mathrm{ml}$ containing $10^{8}$ platelets, were incubated with occasional shaking for $10 \mathrm{~min}$ at $37^{\circ} \mathrm{C}$. Then, $1.5 \mathrm{ml}$ of Tyrode's resuspension buffer was added, the tubes were centrifuged at $1,500 \mathrm{~g}$ for $10 \mathrm{~min}$ at room temperature, and the supernatant fluids were frozen in aliquots for assay of PF4, BTG, and IgG. The platelet pellet was washed once, resuspended in $1 \mathrm{ml}$ of Tyrode's resuspension buffer by sonication, solubilized in $0.5 \%$ Lubrol PX (Sigma Chemical Co.) at $37^{\circ} \mathrm{C}$ for $30 \mathrm{~min}$, centrifuged in an Eppendorf microfuge $(12,000 \mathrm{~g})$ for $5 \mathrm{~min}$, and the supernatant fluid was frozen for assay of platelet-associated IgG.

Assay of PF 4 and BTG. PF4 was assayed by our previously published radioimmunoassay method (27). BTG was assayed by use of a commercial radioimmunoassay kit obtained from Amersham Corp., Arlington Heights, IL. For assay of the total initial platelet content of PF4 and BTG, a parallel $2.5-\mathrm{ml}$ suspension of control platelets was sonicated for four 15-s intervals on ice (Sonic Dismembrator, Artek). These assays were performed on coded samples without knowledge of the platelet treatment data.

IgG assay. IgG was measured by an enzyme-linked immunosorbent assay (ELISA) technique using "Immulon I" plates with U-shaped wells (Dynatech Laboratories, Alexandria, VA). The wells were coated with affinity-purified goat anti-human IgG (Cappel Laboratories, Cochranville, PA) by adding $50 \mu \mathrm{l}$ of a $10 \mu \mathrm{g} / \mathrm{ml}$ solution in sodium carbonate buffer, $\mathrm{pH} 9.6$, to each well and incubating the plate at $4^{\circ} \mathrm{C}$ overnight. Then the antibody solution was poured out and the wells were filled with $1 \%$ BSA in phosphate-buffered saline (PBS), $\mathrm{pH}$ 7.2. After $15 \mathrm{~min}$ at room temperature, the wells were washed twice with PBS containing $0.02 \%$ normal goat serum and $50 \mu$ of the test samples or IgG standard solutions were added to the wells for $60 \mathrm{~min}$ at room temperature. The test samples were diluted fivefold in PBS and 50- $\mu$ l aliquots, equivalent to $10^{6}$ platelets in $0.1 \%$ Lubrol PX, were added to each well. The human IgG standard was prepared from serum by Rivanol (Sigma Chemical Co.) ammonium sulfate precipitation (28), dialyzed against $0.1 \mathrm{M}$ glycine, $0.05 \mathrm{M}$ Tris, $0.02 \%$ sodium azide, $\mathrm{pH} 8.0$, and stored at $4^{\circ} \mathrm{C}$. Purity of the IgG standard was demonstrated by sodium dodecyl sulfate-polyacrylamide gel electrophoresis. The IgG concentration, measured by use of a radial immunodiffusion kit (ICL Scientific, Inc., Sunnyvale, CA), was identical to the total protein assayed by $E_{1 \mathrm{~m} / \mathrm{ml}}^{280 \mathrm{~nm}}=1.40$. The standard curve was prepared from a sample of the IgG standard diluted to $0.5-10.0 \mathrm{ng} / 50$ $\mu \mathrm{l}$ in $0.1 \%$ Lubrol PX in PBS. After incubation, the samples were poured off and the wells were washed three times in PBS-NGS. Then $50 \mu \mathrm{l}$ of BSA-PBS containing $0.125 \mu \mathrm{g}$ of biotinylated affinity-purified goat antihuman IgG (Vector Laboratories, Inc., Burlingame, CA) were added to each well for $30 \mathrm{~min}$ at room temperature, followed by three washes with PBS-NGS. Next $50 \mu \mathrm{l}$ of BSA-PBS containing Avidin D-biotinylated horseradish peroxidase complex ( $0.625 \mu \mathrm{g}$ of each, Vector) were added to each well for $30 \mathrm{~min}$ at room temperature followed by six washes with PBS-NGS. Finally $50 \mu \mathrm{l}$ containing $50 \mu \mathrm{g}$ of $o$-phenylenediamine (Sigma Chemical Co.) in citrate buffer, $\mathrm{pH} 4.5$, with $0.03 \% \mathrm{H}_{2} \mathrm{O}_{2}$ were added to each well and the plate was kept in the dark for $30 \mathrm{~min}$ at room temperature. Color development was read at $450 \mathrm{~nm}$ (Dynatech microELISA minireader, MR 590).

Platelet-associated albumin assay. Lubrol PX-extracts of washed platelets for assay of albumin were prepared as for the measurement of IgG. Albumin was assayed by the same ELISA technique described above, except that goat serum was omitted from the wash buffers and $1 \%$ gelatin was substituted for BSA. Wells were coated with rabbit anti-human albumin (Cappel Laboratories). A human serum albumin standard was obtained from Sigma Chemical Co. The assay was performed with goat anti-human albumin (Cappel) and biotinylated rabbit anti-goat IgG (Vector Laboratories, Inc.).

Immunoblotting. Whole platelets and platelet fractions were solubilized in $2 \%$ sodium dodecyl sulfate (the Lubrol-insoluble pellet was suspended by sonication before solubilization) and electrophoresed on a 7-12\% exponential gradient acrylamide gel, either unreduced or after reduction with $\beta$-mercaptoethanol (29). Following electrophoresis, proteins were transferred onto nitrocellulose $(29,30)$ and $\operatorname{IgG}$ was detected with biotinylated goat anti-human IgG and the "Vectastain" immunoperoxidase system (Vector).

\section{Results}

Morphological localization of platelet IgG. The use of colloidal gold immunoconjugates on frozen thin-sections of resting platelets allowed the study of the intracellular distribution of $\operatorname{IgG}$ antigen. Immunogold particles were found mainly within the matrix of most, but not all, $\alpha$-granules (Fig. 1). Rare gold particles were found on the plasma membrane, or within other organelles. It should be recognized, however, that the membranes of small vesicles are difficult to visualize with this technical procedure. Using the same technique we have previously localized PF4 and BTG in platelet $\alpha$-granules $(20,21)$. However, less label was found for IgG using similar methods. Negligible gold labeling was found when the primary antiserum was replaced by normal rabbit serum.

Normal platelet content of IgG, PF4, BTG, and albumin. The amount of IgG in control platelets for the secretion experiments, $4.38 \pm 1.78 \mathrm{fg} /$ platelet (SD, $n=13$ ), was not different from the amount in platelets assayed directly after two washes $(5.38 \pm 0.85 \mathrm{fg} /$ platelet, $\mathrm{SD}, n=10, p>0.1)$; this indicates that no change occurred in the control platelets during the incubation at $37^{\circ} \mathrm{C}$ and additional wash and centrifugation. These values are the same as reported with other methods $(9,12)$. The Lubrol extract contained all of the platelet IgG as determined by SDSPAGE and immunoblot analysis of whole platelets, the Lubrol extract, and the Lubrol-insoluble pellet. The Lubrol-insoluble pellet material contained no IgG (data not shown). The platelet contents of PF4 and BTG in our experiments were $31.5 \pm 6.0 \mathrm{fg}$ PF4/platelet $(n=11)$ and $45.9 \pm 4.4 \mathrm{fg} \mathrm{BTG} /$ platelet $(n=10)$. Therefore, the molar ratio of PF4 and BTG (assuming both exist as tetrameric molecules in $\alpha$-granules) to IgG in platelets is about $30: 1$. Others have previously reported values for assays of platelet lysates (18.0 fg PF4/platelet, $17.7 \mathrm{fg}$ BTG/platelet) (32) or calculated from assays of serum (13.1 fg PF4/platelet, $41.2 \mathrm{fg} \mathrm{BTG/}$ platelet) (33). The platelet content of albumin in our experiments was $14.5 \pm 4.1 \mathrm{fg} /$ platelet $(n=19)$, which is similar to the previously reported value of $11.8 \mathrm{fg} /$ platelet (34).

Secretion of platelet $\operatorname{IgG}, P F 4$, and $B T G$ after stimulation by thrombin, calcium ionophore A23187, and ADP. Fig. 2 demonstrates that thrombin induces parallel secretion of IgG, PF4, and BTG, beginning at a thrombin concentration of $0.02 \mathrm{U} / \mathrm{ml}$ and reaching $100 \%$ at $0.5 \mathrm{U} / \mathrm{ml}$. In four of the six experiments with thrombin, IgG was measured both in the supernatant fluid and in the platelet pellet, and calculation of percent secretion yielded the same results with both sets of data. SDS-PAGE and immunoblotting of the supernatant fluid using both unreduced and reduced samples demonstrated that intact IgG molecules were secreted by thrombin (data not shown). $\mathrm{PGE}_{1}$ and db- 

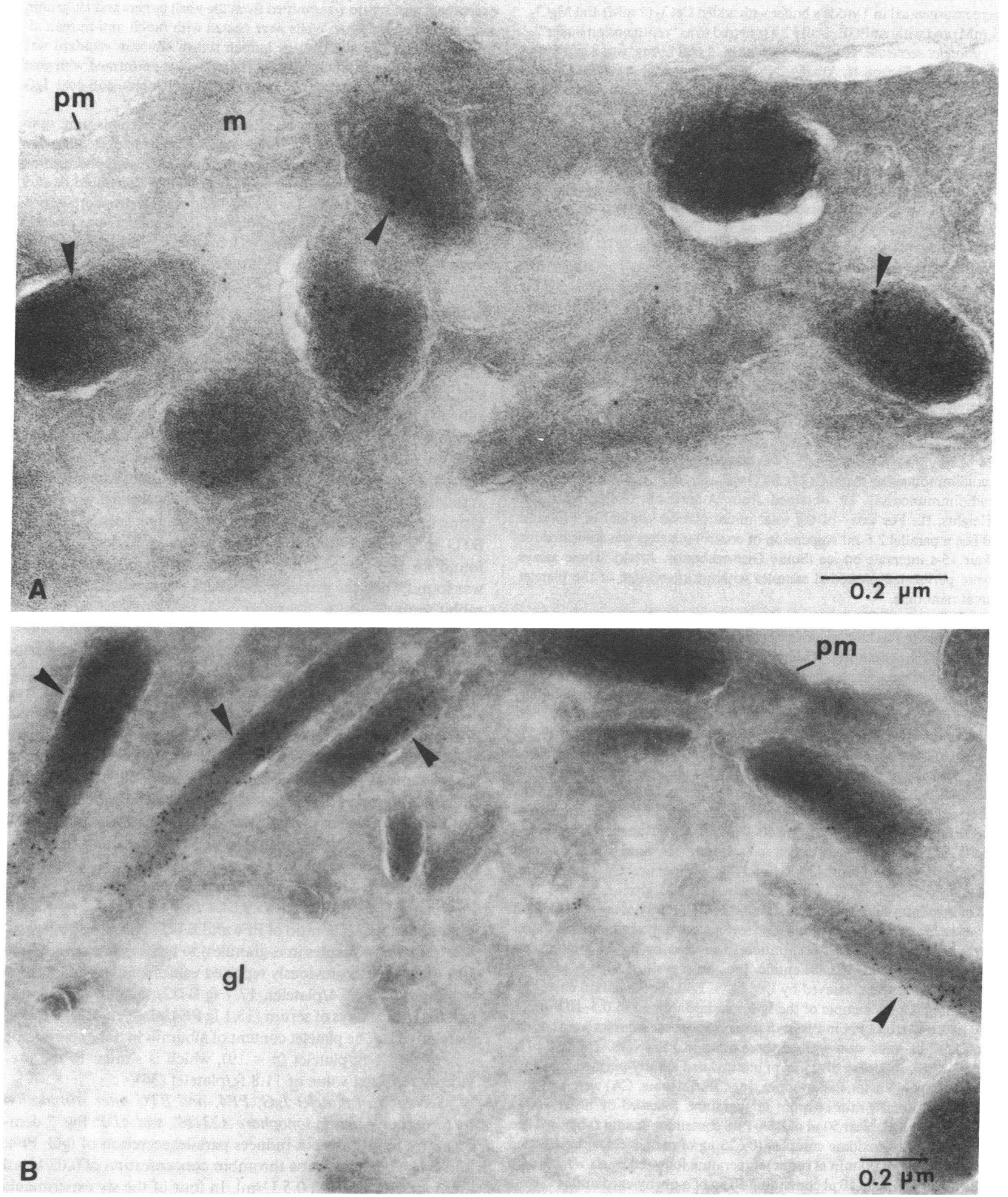

Figure 1. Transmission electron micrographs showing the $\alpha$-granule location of IgG in resting platelets. The frozen thin sections were incubated with anti-IgG and then the immunogold probe, GAR-5, was applied. Note label (arrows) over many of the $\alpha$-granules. The $\alpha$-granules are heterogeneous in size and shape, and elongated granules, as shown here in $(B)$, are commonly seen in our preparations of unanticoagu- lated blood which have been fixed directly from the venipuncture at $37^{\circ} \mathrm{C}$. Similar observations have been made by Cramer et al. (31). pm, plasma membrane; $\mathrm{m}$, mitochondria. The other intracellular membranes probably represent surface-connected cannicular system. The large extracted area is glycogen (gl). A, $\times 100,000 . \mathrm{B}, \times 50,000$. 


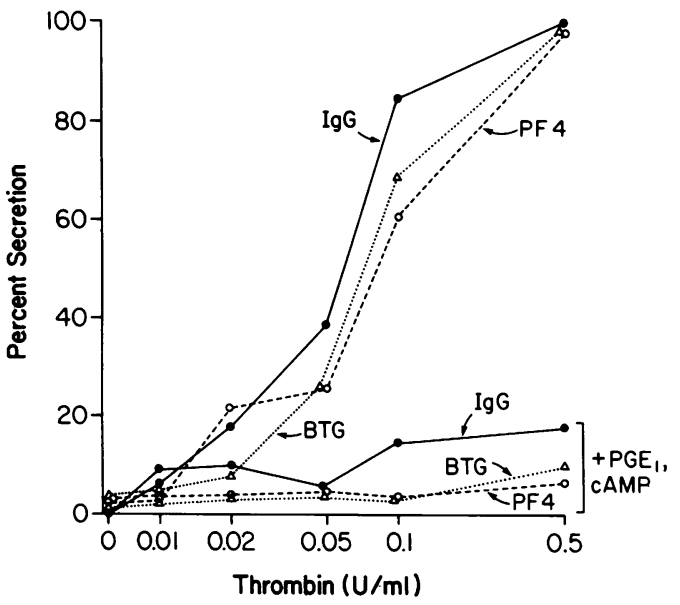

Figure 2. Thrombin-induced secretion of IgG, PF4, and BTG. Washed platelets $(975 \mu \mathrm{l})$ were incubated with $25 \mu \mathrm{l}$ of various concentrations of thrombin or $25 \mu \mathrm{l}$ of Tyrode's buffer alone for $10 \mathrm{~min}$ at $37^{\circ} \mathrm{C}$. The final platelet concentration was $10^{8} / \mathrm{ml}$. IgG secretion was measured by comparing the amount of IgG remaining in the platelets after thrombin treatment with that in control platelets, which was defined as zero secretion. PF4 and BTG secretion was measured by comparison of the amounts appearing in the supernatant fluid in the thrombin-treated and control samples with the amount in a sonicated sample, which was defined as the total platelet content. Where indicated, $\mathrm{PGE}_{1}$ and db-cAMP (final concentrations, $10 \mu \mathrm{g} / \mathrm{ml}$ and $1 \mathrm{mM}$, respectively) were added before thrombin. Data are the mean values with four donors from six (IgG) and five (PF4, BTG) experiments with thrombin alone, and from two experiments with thrombin plus $\mathrm{PGE}_{1}$ and $\mathrm{db}$-cAMP.

cAMP, which inhibit platelet secretion of PF4 in clotting blood (26), markedly and equally diminished thrombin-induced secretion of IgG, PF4, and BTG (Fig. 2).

The calcium ionophore A23187 also caused parallel secretion of IgG, PF4, and BTG, beginning at an ionophore concentration of $0.2 \mu \mathrm{M}$ and reaching a maximum of $60-75 \%$ at $1.0 \mu \mathrm{M}$ (Fig. 3).

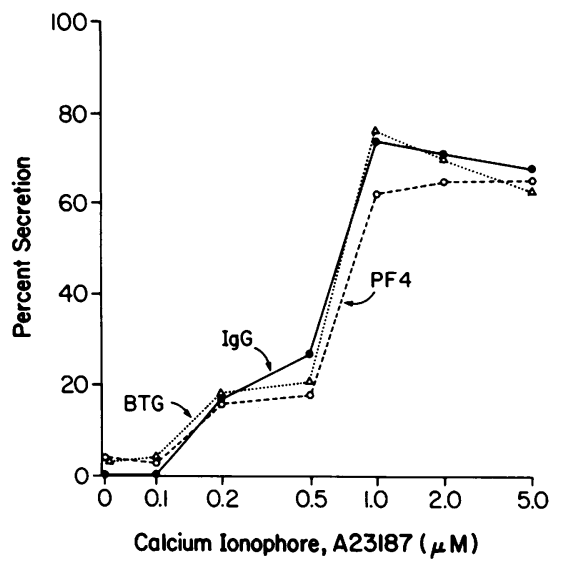

Figure 3. Calcium ionophore A23187-induced secretion of IgG, PF4, and BTG. Washed platelets $(990 \mu \mathrm{l})$ were equilibrated with leupeptin ( $0.4 \mathrm{mM})$, and then incubated with $10 \mu \mathrm{l}$ of various concentrations of ionophore dissolved in ethanol, or with $10 \mu \mathrm{l}$ of ethanol alone, for 10 min at $37^{\circ} \mathrm{C}$. The final platelet concentration was $10^{8} / \mathrm{ml}$. Secretion was measured as described in Fig. 2. Data are the mean values from three experiments with two donors.
In contrast with thrombin and calcium ionophore, ADP causes reversible aggregation but virtually no secretion with washed platelets suspended in $\mathrm{Ca}^{2+}$-containing buffer (35), a model we used in earlier studies on the secretion of the $\alpha$-granule protein thrombospondin $(36,37)$. As in our studies with thrombospondin, ADP caused minimal secretion of IgG, PF4, and BTG, even though visible aggregation occurred (Fig. 4).

\section{Discussion}

Our data demonstrate that platelet IgG is contained within the $\alpha$-granules, the protein-containing secretory organelles (38). This finding is consistent with the early observations on platelet IgG by Davey and Lüscher $(2,3)$ and with recent preliminary observations by Dixon, Wencel-Drake, and Ginsburg (39). IgG is totally secreted in response to thrombin in a reaction inhibited by $\mathrm{PGE}_{1}$ and db-cAMP; it is partially secreted in response to the calcium ionophore A23187 and negligibly secreted in response to ADP. In these reactions the secretion of IgG was identical to that of two other known $\alpha$-granule proteins, PF4 and BTG (19-21). The absence of IgG in platelets treated with 0.5 $\mathrm{U} / \mathrm{ml}$ thrombin suggests that there is little platelet surface binding of $\mathrm{IgG}$, which is consistent with recent observations that normal platelets have less than 400 molecules of $\operatorname{IgG}(<0.1 \mathrm{fg})$ on their surface (15-17), a value undetectable by our assay.

How does IgG come into the platelet $\alpha$-granule? Megakaryocytes synthesize some $\alpha$-granule proteins: von Willebrand factor, fibrinogen, PF4, and coagulation factor V (40-43). Albumin synthesis by young platelets has also been demonstrated (44). There have been no studies of megakaryocyte synthesis of immunoglobulins, although normal human marrow is a rich source of IgG production $(45,46)$.

Alternatively, IgG could be acquired from the plasma and delivered to $\alpha$-granules, a process that might occur during $\alpha$ granule development within megakaryocytes or in mature circulating platelets or both. Several observations suggest that this may be the mechanism by which platelet $\alpha$-granules acquire

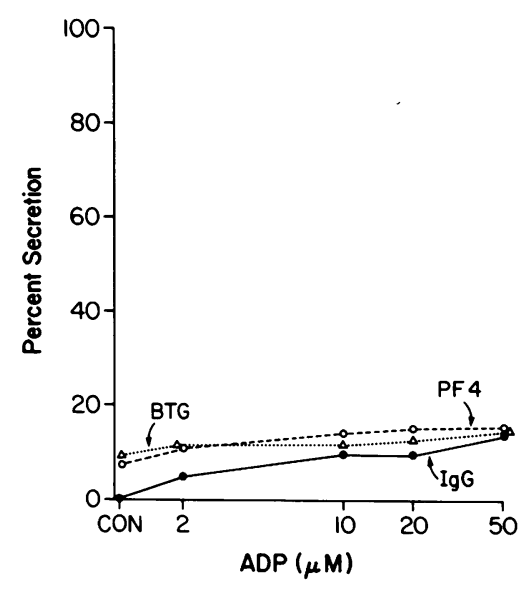

Figure 4. ADP-induced secretion of IgG, PF4, and BTG. Washed platelets $(950 \mu \mathrm{l})$ were incubated with $40 \mu \mathrm{l}$ of human fibrinogen (to achieve a final concentration of $0.5 \mathrm{mg} / \mathrm{ml}$ ) and $10 \mu \mathrm{l}$ of PBS containing various concentrations of ADP, or $10 \mu \mathrm{l}$ of the PBS buffer alone, for $10 \mathrm{~min}$ at $37^{\circ} \mathrm{C}$. The final platelet concentration was $10^{8} / \mathrm{ml}$. Secretion was measured as described in Fig. 2. Data are the mean values from two (BTG), three (PF4), and four (IgG) experiments with two donors. 
IgG: (a) Plasma IgG probably has access to megakaryocytes because IgG (47), like albumin (48), has a large extravascular distribution, $50-55 \%$ of the total body pool. The presence of IgG and albumin in the extravascular compartment of marrow is possible in that endocytosis of some proteins, such as peroxidase and ferritin, has been previously demonstrated in bone marrow endothelium (49). Also megakaryocytes occupy a distinct parasinusoidal location within the marrow cords $(50)$ that may enhance their exposure to plasma proteins. (b) Platelet IgG, both in normal subjects (51) and when it is increased in patients with immune thrombocytopenia $(51,52)$, has the same distribution of heavy-chain subtypes as plasma IgG (53). (c) Platelet IgG concentrations are increased and are correlated with plasma IgG concentrations in a wide variety of hypergammaglobulinemic disorders (54). Also, platelet IgG was absent in a patient with agammaglobulinemia (13). (d) The ratio of the normal platelet concentration of albumin, also an $\alpha$-granule protein (55), to IgG in our experiments was 2.7 , which is similar to the albumin/ IgG concentration ratio in plasma of $3.7(47,48)$. This ratio is preserved by parallel increases in platelet albumin and IgG in patients with immune thrombocytopenia (34), suggesting that IgG and albumin are acquired by similar mechanisms. The ratio of the platelet concentrations of $\mathrm{IgG}$ and albumin to their plasma concentrations is $0.03(47,48)$. In contrast, the platelet concentration of PF4, which is synthesized by the megakaryocyte (41), is 700,000 -fold greater than its plasma concentration (27). (e) The higher platelet IgG concentrations in thrombocytopenic subjects with shorter platelet survival times have been interpreted as indicating that the presence of more antiplatelet antibody causes more rapid platelet destruction $(56,57)$. However, these data are also consistent with a hypothesis that younger platelets naturally contain more $\mathrm{IgG}$, as is suggested by the higher platelet IgG concentrations in dogs recovering from plateletpheresis (58). These observations are consistent with a hypothesis that IgG is taken up from plasma by megakaryocytes. Although movement of exogenous proteins into secretory granules has not yet been demonstrated in megakaryocytes or platelets, it has been described for granulocytes and lymphoid cells (59). Further studies on the origin and packaging of platelet $\alpha$-granule proteins are currently underway.

If platelet IgG is, in fact, a mirror of plasma IgG packaged into the $\alpha$-granules, what is its function? No hemostatic function is apparent, but the delivery of IgG to a site of primary hemostasis is consistent with the platelet's proposed role as an inflammatory cell $(60,61)$. Platelets circulating adjacent to the vessel wall are the first cells to accumulate at the point of vascular injury, and secretion of their IgG may augment the barrier to infection by virtue of its ability to opsonize certain microorganisms. This role of platelets (or hemocytes) appears to be critical in more primitive life forms (60), but its importance in human physiology is unknown.

\section{Acknowledgments}

We thank Ms. Betsy Vokac for teaching us the IgG assay; Ms. Yvonne Jacques for her technical assistance; Dr. Rodger McEver, Dr. Jean-Philippe Rosa, and Dr. Thomas Kunicki for their helpful discussions and suggestions; and Mrs. Judi Skinner for the preparation of this manuscript.

This work was supported by grants from National Heart, Lung, and Blood Institute (HL 19996, HL 23578, and HL 31610), the National Aeronautics and Space Administration (NAG 9-5), and a Merit Review Award from the Veterans Administration.

\section{References}

1. Salmon, J. 1958. Etude immunoélectrophorétique des antigènes plaquettaires humains. Schweiz. Med. Wochenschr. 88:1047-1049.

2. Davey, M. G., and E. F. Lüscher. 1966. Platelet proteins. In Biochemistry of Blood Platelets. E. Kowalski and S. Niewiarowski, editors. Academic Press, New York. 9-22.

3. Davey, M. G., and E. F. Lüscher. 1968. Release reactions of human platelets induced by thrombin and other agents. Biochim. Biophys. Acta. 165:490-506.

4. Nachman, R. L. 1968. Platelet proteins. Semin. Hematol. 5:1831.

5. Davey, M. G., and E. F. Lüscher. 1967. Actions of thrombin and other coagulant and proteolytic enzymes on blood platelets. Nature (Lond.). 216:857-858.

6. Dixon, R., W. Rosse, and L. Ebbert. 1975. Quantitative determination of antibody in idiopathic thrombocytopenic purpura. $N$. Engl. J. Med. 292:230-236.

7. Luiken, G. A., R. McMillan, A. L. Lightsey, P. Gordon, S. Zevely, I. Schulman, T. J. Gribble, and R. L. Longmire. 1977. Platelet-associated IgG in immune thrombocytopenic purpura. Blood. 50:317-325.

8. Cines, D. B., and A. D. Schreiber. 1979. Immune thrombocytopenia. Use of a Coombs' antiglobulin test to detect IgG and C3 on platelets. N. Engl. J. Med. 300:106-111.

9. McMillan, R. 1981. Chronic idiopathic thrombocytopenic purpura. N. Engl. J. Med. 304:1135-1147.

10. Kelton, J. G. 1983. The measurement of platelet-bound immunoglobulins: an overview of the methods and the biological relevance of platelet-associated IgG. Prog. Hematol. 13:163-199.

11. Pfueller, S. L., L. Cosgrove, B. G. Firkin, and D. Tew. 1981. Relationship of raised platelet IgG in thrombocytopenia to total platelet protein content. Br. J. Haematol. 49:293-302.

12. Shulman, N. R., and J. V. Jordan, Jr. 1982. Platelet immunology. In Hemostasis and Thrombosis. R. W. Colman, J. Hirsh, V. J. Marder, and E. W. Salzman, editors. Lippincott, Philadelphia. 274-342.

13. McMillan, R., R. S. Smith, R. L. Longmire, R. Yelenosky, R. T. Reid, and C. G. Craddock. 1971. Immunoglobulins associated with platelets. Blood. 37:316-322.

14. Kelton, J. G., G. Denomme, A. Lucarelli, J. Garvey, P. Powers, and C. Carter. 1985. Comparison of the measurement of surface or total platelet-associated IgG in the diagnosis of immune thrombocytopenia. Am. J. Hematol. 18:1-5.

15. Leporrier, M., G. Dighiero, M. Auzemery, and J. L. Binet. 1979. Detection and quantification of platelet-bound antibodies with immunoperoxidase. Br. J. Haematol. 42:605-611.

16. LoBuglio, A. F., W. S. Court, L. Vinocur, J. G. Maglott, and G. M. Shaw. 1983. Immune thrombocytopenic purpura. Use of a ${ }^{125}$ Ilabeled antihuman IgG monoclonal antibody to quantify platelet-bound IgG. N. Engl. J. Med. 309:459-463.

17. Shaw, G. M., J. Axelson, J. G. Maglott, and A. F. LoBuglio. 1984. Quantification of platelet-bound IgG by ${ }^{125} \mathrm{I}$-staphylococcal protein $A$ in immune thrombocytopenic purpura and other thrombocytopenic disorders. Blood. 63:154-161.

18. George, J. N., L. L. Thoi, and R. K. Morgan. 1981. Quantitative analysis of platelet membrane glycoproteins: effect of platelet washing procedures and isolation of platelet density subpopulations. Thromb. Res. 23:69-77.

19. Sander, H. J., J. W. Slot, B. N. Bouma, P. A. Bolhuis, D. S. Pepper, and J. J. Sixma. 1983. Immunocytochemical localization of fibrinogen, platelet factor 4 , and beta-thromboglobulin in thin frozen sections of human blood platelets. J. Clin. Invest. 72:1277-1287.

20. Stenberg, P. E., M. A. Shuman, S. P. Levine, and D. F. Bainton. 1984. Optimal techniques for immunocytochemical demonstration of $\beta$-thromboglobulin, platelet factor 4 , and fibrinogen in the alpha granules of unstimulated platelets. Histochem. J. 16:983-1001.

21. Stenberg, P. E., M. A. Shuman, S. P. Levine, and D. F. Bainton. 1984. Redistribution of alpha-granules and their contents in thrombinstimulated platelets. J. Cell Biol. 98:748-760. 
22. Tokuyasu, K. T. 1980. Immunochemistry on ultrathin frozen sections. Histochem. J. 12:381-403.

23. Griffiths, G., R. Brands, B. Burke, D. Louvard, and G. Warren. 1982. Viral membrane proteins acquire galactose in trans Golgi cisternae during intracellular transport. J. Cell. Biol. 95:781-792.

24. Mustard, J. F., D. W. Perry, N. G. Ardlie, and M. A. Packham. 1972. Preparation of suspensions of washed platelets. Br. J. Haematol. 22:193-204.

25. Kunicki, T. J., P. J. Newman, P. L. Amrani, and M. W. Mosesson. 1985. Human platelet fibrinogen. Purification and hemostatic properties. Blood. In press.

26. Shuman, M. A., and S. P. Levine. 1980. Relationship between secretion of platelet factor 4 and thrombin generation during in vitro blood clotting. J. Clin. Invest. 65:307-313.

27. Levine, S. P., and L. S. Krentz. 1977. Development of a radioimmunoassay for human platelet factor 4. Thromb. Res. 11:673-686.

28. Heide, K., and H. G. Schwick. 1978. Salt fractionation of immunoglobulins. In Handbook of Experimental Immunology, Vol. I: Immunochemistry. D. M. Wier, editor. Blackwell Scientific Publications, Oxford. Third edition. 7.1-7.11.

29. Kieffer, N., B. Boizard, D. Didry, J.-L. Wautier, and A. T. Nurden. 1984. Immunochemical characterization of the platelet-specific alloantigen Lek: a comparative study with the $\mathrm{P}^{\mathrm{Al}}$ alloantigen. Blood. 64: 1212-1219.

30. Towbin, H., T. Staehelin, and J. Gordon. 1979. Electrophoretic transfer of proteins from polyacrylamide gels to nitrocellulose sheets: procedure and some applications. Proc. Natl. Acad. Sci. USA. 76:43504354.

31. Cramer, E. M., W. Vainchenker, G. Vinci, J. Guichard, and J. Breton-Gorius. 1985. Gray platelet syndrome: immunoelectron microscopic localization of fibrinogen and von Willebrand factor in platelets and megakaryocytes. Blood. In press.

32. Weiss, H. J., L. D. Witte, K. L. Kaplan, B. A. Lages, A. Chernoff, H. L. Nossel, D. S. Goodman, and H. R. Baumgartner. 1979. Heterogeneity in storage pool deficiency. Blood. 54:1296-1319.

33. Files, J. C., T. W. Malpass, E. K. Yee, J. L. Ritchie, and L. A. Harker. 1981. Studies of human platelet $\alpha$-granule release in vivo. Blood. 58:607-618.

34. Kelton, J. G., and K. Steeves. 1983. The amount of plateletbound albumin parallels the amount of IgG on washed platelets from patients with immune thrombocytopenia. Blood. 62:924-927.

35. Mustard, J. F., D. W. Perry, R. L. Kinlough-Rathbone, and M. A. Packham. 1975. Factors responsible for ADP-induced release reaction of human platelets. Am. J. Physiol. 228:1757-1765.

36. George, J. N. 1978. Studies on platelet plasma membranes. IV. Quantitative analysis of platelet membrane glycoproteins by $\left({ }^{125} \mathrm{I}\right)$-diazotized duodosulfanilic acid labeling and SDS-polyacrylamide gel electrophoresis. J. Lab. Clin. Med. 92:430-446.

37. George, J. N., R. M. Lyons, and R. K. Morgan. 1980. Membrane changes associated with platelet activation. J. Clin. Invest. 66:1-9.

38. George, J. N., A. T. Nurden, and D. R. Phillips. 1984. Molecular defects in interactions of platelets with the vessel wall. $N$. Engl. J. Med. 311:1084-1098.

39. Dixon, D. B., J. D. Wencel-Drake, and M. H. Ginsburg. 1983. Localization of platelet-associated IgG in alpha granules. Blood. 62:243a. (Abstr.)

40. Nachman, R. L., R. Levine, and E. A. Jaffe. 1977. Synthesis of factor VIII antigen by cultured guinea pig megakaryocytes. J. Clin. Invest. 60:914-921.

41. Ryo, R., A. Nakeff, S. S. Huang, M. Ginsberg, and T. F. Deuel. 1983. New synthesis of a platelet-specific protein: platelet factor 4 synthesis in a megakaryocyte-enriched rabbit bone marrow culture system. J. Cell Biol. 96:515-520.
42. Leven, R. M., P. K. Schick, and A. Z. Budzinski. 1985. Fibrinogen biosynthesis in isolated guinea pig megakaryocytes. Blood. 65:501-504.

43. Chiu, H. C., P. K. Schick, and R. W. Colman. 1985. Biosynthesis of factor $\mathrm{V}$ in isolated guinea pig megakaryocytes. J. Clin. Invest. 75: 339-346.

44. Kieffer, N., N. Debili, J. P. Farcet, W. Vainchenker, and J. BretonGorius. 1985. Biosythesis of major membrane and $\alpha$-granular glycoproteins in human platelets. Thromb. Haemostasis. 54:179. (Abstr.)

45. McMillan, R., R. L. Longmire, R. Yelenosky, J. E. Lang, V. Heath, and C. G. Craddock. 1972. Immunoglobulin synthesis by human lymphoid tissues: normal bone marrow as a major site of IgG production. J. Immunol. 109:1386-1394.

46. Gyotoku, Y., M. Mori, Y. Nonaka, Y. Nagata, and Y. Saito. 1985. Differences of immunoglobulin secreting cells in bone marrow from those in circulation: relevance to their development. Br. J. Haematol. 59:647-657.

47. Waldmann, T. A., and W. Strober. 1969. Metabolism of immunoglobulins. Prog. Allergy. 13:1-110.

48. Sterling, K. 1951. The turnover rate of serum albumin in man as measured by ${ }^{131} \mathrm{I}$-tagged albumin. J. Clin. Invest. 30:1228-1237.

49. DeBruyn, P. P. H. 1981. Structural substrates of bone marrow function. Semin. Hematol. 18:179-193.

50. Lichtman, M. A., J. K. Chamberlain, W. Simon, and P. A. Santillo. 1978. Parasinusoidal location of megakaryocytes in marrow: a determinant of platelet release. Am. J. Hematol. 4:303-312.

51. Rosse, W. F., J. P. Adams, and W. J. Yount. 1980. Subclasses of IgG antibodies in immune thrombocytopenic purpura. Br. J. Haematol. 46:109-114.

52. Hymes, K., P. H. Schur, and S. Karpatkin. 1980. Heavy-chain subclass of bound antiplatelet IgG in autoimmune thrombocytopenic purpura. Blood. 56:84-87.

53. Natvig, J. B., and H. G. Kunkel. 1973. Human immunoglobulins: classes, subclasses, genetic varients, and idiotypes. Adv. Immunol. 16:159.

54. McGrath, K. M., J. J. Stuart, and F. Richards, II. 1979. Correlation between serum IgG, platelet membrane IgG, and platelet function in hypergammaglobulinemic states. Br. J. Haematol. 42:585-591.

55. Sixma, J. J., A. van den Berg, M. Schiphorst, H. J. Geuze, and J. McDonagh. 1984. Immunocytochemical localization of albumin and factor XIII in thin cryosections of human blood platelets. Thromb. Haemostasis. 51:388-391.

56. Kernoff, L. M., K. C. H. Blake, and D. Shackleton. 1980. Influence of the amount of platelet-bound IgG on platelet survival and site of sequestration in autoimmune thrombocytopenia. Blood. 55:730-733.

57. Mueller-Eckhardt, C., G. Mueller-Eckhardt, W. Kayser, R. M. Voss, J. Wegner, and E. Kuenzlen. 1982. Platelet-associated IgG, platelet survival, and platelet sequestration in thrombocytopenic states. $B r . J$. Haematol. 52:49-58.

58. Shulman, N. R., C. Leissinger, A. Hotchkiss, and C. Kautz. 1982. The nonspecific nature of platelet-associated IgG. Clin. Res. 30:561A. (Abstr.)

59. Dvorak, A. M., S. J. Klebanoff, W. R. Henderson, R. A. Monahan, K. Pyne, and S. J. Galli. 1985. Vesicular uptake of eosinophil peroxidase by guinea pig basophils and by cloned mouse mast cells and granulecontaining lymphoid cells. Am. J. Path. 118:425-438.

60. Nachman, R. L., and B. B. Weksler. 1980. The platelet as an inflammatory cell. In The Cell Biology of Inflammation. G. Weismann, editor. Elsevier/North Holland, Amsterdam. 145-160.

61. Henson, P. M., and M. H. Ginsburg. 1981. Immunological reactions of platelets. In Platelets in Biology and Pathology. Vol. 2. J. L. Gordon, editor. Elsevier/North Holland, Amsterdam. 265-308. 